\title{
A dicynodont-theropod association in the latest Triassic of Poland
}

Jerzy Dzik, Tomasz Sulej, and Grzegorz Niedźwiedzki

Acta Palaeontologica Polonica 53 (4), 2008: 733-738 doi:http://dx.doi.org/10.4202/app.2008.0415

It is generally accepted that during the Triassic the composition of tetrapod faunas underwent a series of fundamental transformations, mainly as a result of diversification of archosaurs and decline of therapsids (Benton 1994, 2004, 2006). The last herbivorous basal synapsids, dicynodonts, disappeared from the record in the early Norian of the Americas, about $220 \mathrm{Ma}$ (Langer et al. 2007), being unknown from the Late Triassic of Europe. Here, we report a partially articulated skeleton and isolated bones of a giant rhino-size dicynodont in the Upper Triassic fluvial sediments at Lisowice (Lipie Śląskie clay-pit) in southern Poland. Paleobotanical data indicate an early Rhaetian age for the fauna (Dzik et al. 2008; Niedźwiedzki and Sulej 2008). The dicynodont bones are associated with bones of carnivorous dinosaurs, pterosaurs, as well as capitosaur and plagiosaur amphibians. Dicynodonts were represented in the Germanic Basin throughout the Late Triassic, as proven by findings of smaller dicynodonts in older deposits in the same area, associated there with temnospondyl amphibians. It appears, thus, that the fossil record of tetrapod succession in the Late Triassic was strongly controlled by ecological factors and biased by uneven representation of particular environments. The Lisowice assemblage proves that faunas dominated by dicynodonts did not entirely disappear at least until the end of the Triassic.

Jerzy Dzik [dzik@twarda.pan.pl], Instytut Paleobiologii PAN, Twarda 51/55, PL-00-818 Warszawa, Poland and Instytut Zoologii Uniwersytetu Warszawskiego, ul. Banacha 2, PL-02-097 Warszawa, Poland; Tomasz Sulej [ulej@ twarda.pan.pl ], Instytut Paleobiologii PAN, ul. Twarda 51/55, PL-00-818 Warszawa, Poland; Grzegorz Niedźwiedzki [gniedzwiedzki@biol.uw.edu.pl], Instytut Zoologii Uniwersytetu Warszawskiego, ul. Banacha 2, PL-02-079 Warszawa, Poland.

This is an open-access article distributed under the terms of the Creative Commons Attribution License (for details please see creativecommons.org), which permits unrestricted use, distribution, and reproduction in any medium, provided the original author and source are credited. 
Fofif Full text $(390.9 \mathrm{kB})$ 